\title{
PENERAPAN MODEL PEMBELAJARAN SELF DESIGN PROJECT LEARNING UNTUK MENINGKATKAN KOMPETENSI SISWA SMK PADA KOMPETENSI PEMESINAN FRAIS KOMPLEKS
}

\author{
Puji D. Lestari ${ }^{1}$, Aam Hamdani ${ }^{2}$, Enda Permana ${ }^{3}$ \\ Departemen Pendidikan Teknik Mesin \\ Universitas Pendidikan Indonesia \\ Jl. Dr. Setiabudhi No. 207 Bandung 40154 \\ puji_dl@yahoo.com
}

\begin{abstract}
ABSTRAK
Tujuan penelitian ini adalah untuk mengetahui peningkatan hasil belajar dan nilai uji kompetensi siswa dengan penerapan model pembelajaran self design project learning pada mata pelajaran mesin frais lanjut. Metode penelitian ini menggunakan metode Quasi eksperimen. Sampel penelitian berjumlah 63 siswa kelas XII di SMK Negeri 2 Kota Bandung. Hasil penelitian ini menunjukan bahwa self design project learning berpengaruh terhadap peningkatan hasil belajar dan nilai uji kompetensi siswa yang bertujuan agar mutu lulusan sesuai dengan kebutuhan dunia industri, maka tentu diperlukan suatu perencanaan program pendidikan dan pembelajaran dimana siswa dilatih dalam suatu kondisi lingkungan yang mirip pada saat nanti mereka bekerja.
\end{abstract}

Kata kunci: self design project learning, hasil belajar, kompetensi, mesin frais.

\section{PENDAHULUAN}

Pendidikan kejuruan sebagai salah satu subsistem dari pendidikan nasional, sesuai dengan ketentuan pada Undang-Undang No. 20 tahun 2003 tentang Sistem Pendidikan Nasional (Sisdiknas), mempunyai tujuan utama yaitu menyiapkan tamatannya memasuki dunia kerja. Oleh karena itu, sistem pendidikan harus disesuaikan dengan kebutuhan pembangunan di setiap bidang yang memerlukan keahlian dan keterampilan untuk menghasilkan produktivitas, mutu dan efisiensi kerja (Wena, 2011).

Sekolah Menengah Kejuruan (SMK) sebagai bentuk satuan pendidikan kejuruan sebagaimana ditegaskan dalam penjelasan Pasal 15 UU Sisdiknas. Pendidikan menengah yang lebih mengarahkan siswa untuk memiliki keahlian khusus pada bidang tertentu. SMK memiliki tujuan pokok yaitu memiliki peran strategis untuk mempersiapkan peserta didik agar siap bekerja baik secara mandiri (wiraswasta) atau tenaga kerja tingkat menengah, untuk mengisi kebutuhan dunia usaha dan industri artinya untuk menjadi tenaga kerja, harus memiliki pengetahuan, keterampilan dan sikap yang sesuai dengan kualifikasi dunia kerja pengguna lulusan (Amir, 2009).

\footnotetext{
${ }^{1}$ Mahasiswa Departemen Pendidikan Teknik Mesin FPTK UPI

${ }^{2}$ Dosen Departemen Pendidikan Teknik Mesin FPTK UPI

${ }^{3}$ Dosen Departemen Pendidikan Teknik Mesin FPTK UPI
} 
Kondisi penyelenggaraan pendidikan selama ini pada umumnya masih berorientasi lebih mementingkan aspek kognitif. Model pembelajaran ceramah, pada model ini interaksi selalu berpusat kepada pendidik sehingga materi yang dikuasai siswa terbatas hanya pada apa yang telah dikuasai dan disampaikan guru. Ini merupakan kelemahan yang paling dominan pada model ceramah. Apa yang telah disampaikan guru itulah yang diperolehnya dan dikuasainya. Para siswa di sekolah disajikan berbagai informasi secara kognitif, sedangkan aspek afektifnya terabaikan (Hamalik, 2011). Akibat dari penyelengaraan dan pembelajaran seperti ini, sebagian besar masih banyak lulusan SMK yang tidak mampu memenuhi persyaratan kerja di industri.

Rata-rata keterserapan lulusan yang paling tinggi adalah bekerja. Kompetensi lulusan SMK harus sesuai dengan kualifikasi di industri. Namun rendahnya kualitas lulusan SMK diindikasikan dari hasil observasi di lapangan yang menunjukkan bahwa sebagian lulusan SMK kurang mampu menyesuaikan diri dengan perubahan maupun perkembangan IPTEK dan kurang bisa mengembangkan diri. Salah satu indikasi dari temuan bahwa pembelajaran di SMK belum efektif dan belum mengembangkan kemampuan peserta didik. Salah satu faktor diantaranya fasilitas praktek di sekolah masih berada di bawah standar dari alat yang dipakai di industri, sehingga siswa yang menjadi pekerja atau operator membutuhkan pelatihan-pelatihan sesuai bidang garapannya.

Model pembelajaran dirancang sedemikian rupa agar sesuai dengan siswa yang memiliki motivasi tinggi, dan sesuai juga dengan siswa yang memiliki motivasi belajar yang rendah. Model pembelajaran dapat berfungsi untuk memberikan pernyataan singkat dan rangsangan yang khusus mengenai isi materi dari mata pelajaran yang telah dipelajari (Rusman, 2011). Self design project learning (SDPL) adalah salah satu model pembelajaran yang dipandang cocok untuk digunakan sebagai alternatif dalam proses pembelajaran di pendidikan kejuruan (Hamdani, 2015). Model pembelajaran SDPL ini bertujuan agar mutu lulusan SMK sesuai dengan kebutuhan dunia industri, maka tentu diperlukan suatu perencanaan program pendidikan dan pembelajaran dimana siswa dilatih dalam suatu kondisi lingkungan yang mirip pada saat nanti mereka bekerja. Pengenalan dunia kerja sangatlah penting untuk calon lulusan SMK. Selain itu agar luaran pembelajaran sejalan dengan kondisi pekerjaan di dunia industri, maka diperlukan pembekalan ilmu pengetahuan melalui model pengembangan kompetensi kerja industri siswa SMK bidang keahlian pemesinan. 


\section{METODE PENELITIAN}

Penelitian ini menggunakan pendekatan kuantitatif, metode penelitian yang akan digunakan adalah quasi experimental design dengan menggunakan desain pretest-posttest, non-equivalent control group design. Penelitian quasi eksperimen ini melibatkan dua kelompok peserta didik, yaitu kelompok eksperimen dan kelompok kontrol. Kedua kelompok subjek populasi dalam penelitian ini adalah siswa kelas XII Teknik Pemesinan SMK N 2 Kota Bandung dengan jumlah populasi sebanyak 63 siswa. Teknik pengambilan sampel yang digunakan yaitu sampel acak 2 kelas pada kelas XII , pada penelitian ini sample 32 orang pada kelas eksperimen dan 31 orang pada kelas kontrol. Kelompok tersebut sama-sama diberikan pre-test dan post test, tetapi diberi perlakuan yang berbeda. Kelas eksperimen diberikan model pembelajaran self design project learning, sedangkan kelas kontrol tidak diberikan penggunaan self design project learning atau belajar dengan model pembelajaran yang biasa dilakukan disekolah.

Instrumen yang digunakan pada penelitian ini adalah tes objektif. Instrumen ini dijadikan sebagai acuan untuk mengetahui kemampuan atau hasil belajar siswa. Pemberian soal tes kognitif dalam merancang langkah kerja pembuatan produk roda gigi dan tes berupa praktikum membuat roda gigi sesuai dengan rancangan yang telah dibuat untuk mengetahui peningkatan kompetensi siswa dalam bidang pemesinan frais. Instrumen ini mengukur pengetahuan siswa pada ranah kognitif dari level pengetahuan hingga aplikasi.

Pengolahan data merupakan bagian penting dalam suatu penelitian, karena dengan pengolahan data, maka data tersebut dapat diberi arti yang berguna dalam pemecahan suatu masalah penelitian. Data berupa skor pre test dan post test diperoleh dari kelompok eksperimen dan kelompok kontrol akan dianalisis dengan beberapa pengujian.

\section{HASIL PENELITIAN}

Data hasil penelitian ini diperoleh dari hasil pre-test, post-test dan praktikum uji kompetensi. Data ini diambil dari dua kelompok sampel 32 siswa pada kelas eksperimen dan 31 siswa pada kelas kontrol, dengan jumlah 63 orang siswa kelas XII teknik pemesinan SMK N 2 Kota Bandung sebagai kelas eksperimen yang menggunakan self design project learning maupun belajar dengan model pembelajaran yang biasa digunakan disekolah.

Deskripsi data hasil penelitian pre-test maupun post-test dari sampel pada kelas yang menggunakan self design project learning maupun belajar dengan konvensional. 
Hasil belajar kelas yang menggunakan SDPL, skor tertinggi untuk pre-test sebesar 1,89 skor terendah 1,71 dan rata-rata 1,80. Sedangkan untuk skor tertinggi post-test sebesar 3,20 terendah sebesar 2,75 dan rata-rata 2,90. Gain tertinggi yaitu sebesar 0,49 gain terendah yaitu 0,37 dan gain rata-rata yaitu 0,43. Pada kelas kontrol yang menggunakan model pembelajaran yang biasa digunakan disekolah, skor tertinggi untuk pre-test sebesar 1,94 skor terendah 1,63 dan rata-rata skor 1,78. Sedangkan pada post-tes, skor tertinggi 2,75 skor terendah 2,41 dan skor rata-rata 2,58. Gain tertinggi yaitu 0,39, gain terendah yaitu 0,22 dan gain rata-rata yaitu 0,31 .

Nilai pretest pada kelas ekperimen dan kelas kontrol, pada kelas kontrol 6,5\% mendapatkan nilai D+ dan 93,5\% mendapatkan nilai C-. Sedangkan pada kelas eksperimen 100\% siswa mendapatkan nilai C-. Nilai posttest pada kelas ekperimen dan kelas kontrol, pada kelas kontrol 93,5\% mendapatkan nilai $\mathrm{C}+$ dan 9,7 \% mendapatkan nilai B-. Sedangkan pada kelas eksperimen 90,6\% siswa mendapatkan nilai B- dan 9,4\% mendapatkan nilai $\mathrm{B}$.

Hasil uji kompetensi dari sampel pada kelas yang menggunakan model pembelajaran yang biasa digunakan di sekolah. Hasil uji kompetensi kelas eksperimen, skor tertinggi 84,40 terendah 78,80 dan rata-rata 82,8. Pada kelas kontrol, skor tertinggi sebesar 80, skor terendah 77,59 dan rata-rata skor 78,64.

\section{PEMBAHASAN}

Presentase kelulusan nilai siswa yang didapat pada praktikum uji kompetensi kelas eksperimen maupun kelas kontrol, dapat dilihat bahwa kedua kelas memenuhi syarat batas minimum penilaian BSNP dengan batas minimum <70, namun dapat dilihat perbedaan nilai antara kelas eksperimen dan kelas kontrol. Nilai uji kompetensi yang di dapatkan untuk kelas kontrol 93,5\% pada rentang nilai 70-79 dan pada rentang nilai 80-89 sebesar $6,4 \%$. Sedangkan pada kelas kontrol 15,6\% pada rentang nilai 70-79 dan pada rentang nilai $80-89$ sebesar $84,4 \%$.

Model pembelajaran SDPL ini lebih efektif diterapkan dalam pembelajran produktif, hal ini dikarenakan model pembelajaran SDPL ini dalam proses pengajaran mesin frais materi membuat roda gigi memberi pengaruh terhadap peningkatan hasil belajar dan nilai praktik uji kompetensi. Model SDPL guru mengarahkan siswa untuk belajar mandiri dan dilatih dalam suatu kondisi lingkungan seperti di industri (Huda, 2014). 
Model pembelajaran SDPL ini dapat melatih siswa untuk membuat suatu project melalui langkah-langkah mulai dari memilih jenis produk, perencanaan produk. Evaluasi dan pembelajaran produksi (melaksanakan pembuatan produk) sehingga siswa dapat bekerja mandiri seperti halnya di industri (Sudjana, 2009). Model pembelajaran ini dapat diterapkan bila didukung dengan fasilitas yang lengkap dan memadai seperti halnya diindustri. Proses pembelajaran dilakukan secara mandiri. Jika fasilitas alat atau mesin kurang memadai, maka proses pembelajaran menggunakan Model pembelajaran SDPL ini akan terhambat dan memakan banyak waktu sehingga pembelajaran ini tidak akan efektif dan tidak akan maksimal. Model pembelajaran ini agar memotivasi siswa agar lebih mandiri dan meningkatkan kompetensi yang dimiliki sehingga siswa sudah dapat bekerja seperti halnya diindustri dan lulusannya semakin siap untuk bekerja diindustri.

\section{KESIMPULAN}

Kesimpulan penelitin ini, sebagai berikut terdapat perbedaan kompetensi peserta didik antara kelas eksperimen yang menggunakan model pembelajaran Self Design Project Learning dengan kelas kontrol yang menggunakan model pembelajaran yang biasa dilakukan disekolah pada mata pelajaran mesin frais kompleks. Ada perbedaan peningkatan hasil belajar dan perbedaan nilai uji kompetensi pada pembelajaran Self Design Project Learning dibandingkan dengan yang menggunakan model pembelajaran yang biasa digunakan di sekolah.

\section{DAFTAR PUSTAKA}

Amir, M. (2009). Inovasi Pendidikan melalui Problem Based Learning. Jakarta: Kencana Prenada Media Group.

Hamalik. (2011). Proses Belajar Mengajar. Jakarta: Bumi Aksara.

Hamdani, A. (2015) Self Designed Project basedLearning In The Lathe Machining Fileld. International Converence on Inovation Engineering and Vocational Education, 14 November 2015.

Huda, M. (2014). Model-Model Pengajaran dan Pembelajaran: Isu-Isu Metodis dan Paradigmatis. Yogyakarta: Pustaka Pelajar.

Rusman. (2011). Model-Model Pembelajaran Mengembangkan Profesionalisme Guru, Cet. 4. Jakarta: Raja Grafindo Permai. 
Sanjaya, W. (2008). Strategi Pembelajaran Berorientasi Standar Proses Pendidikan. Jakarta: Kecana Prenada Media Group.

Sudjana,N. ( 2009) Penilaian Hasil Proses Belajar Mengajar. Bandung: PT. Ramaja Rosdakarya.

Wena. (2011). Strategi Pembelajaran Inovatif Kontamporer Suatu Pendekatan Tinjauan Konseptual Operasional. Jakarta: Bumi Aksara. 